\section{Subspecific status of the southern Indian population of Nyctemera coleta (Lepidoptera: Arctiidae)}

\author{
Peter Smetacek \\ The Retreat, Jones Estate, P.O. Bhimtal, Nainital \\ Uttarakhand 263136, India \\ Email: petersmetacek@rediffmail.com
}

Nyctemera coleta (Stoll, 1781) is a widespread Asian taxon, with a known distribution through the Oriental Region to Japan and New Guinea (Holloway 1988). Across this range, three subspecies are currently recognized. These are $N$. coleta coleta from Assam to Singapore, Java and Malacca; $N$. coleta melas Röber, 1891 from Ceram, Bangkai and the Moluccas and N. coleta nigrovenosa Moore, 1879 from Sri Lanka. Nyctemera melaneura (Butler, 1883) from Nias was also considered a subspecies of $N$. coleta but this placement is invalid according to the card index in the Natural History Museum (NHM), London (Beccaloni et al. 2003).

In recent years, the moth has been found to be common in suitable localities in peninsular India. However, it does not seem to have been reported from there in the literature. There are specimens from peninsular India in the collection of the Agricultural University, Coimbatore, Tamil Nadu. Besides, Julie Valsarajan (Bengaluru) photographed this moth in Kodagu, Karnataka in October 2008 and Kousik Nandy (Bengaluru) photographed a

Date of publication (online): 26 April 2010

Date of publication (print): 26 April 2010

ISSN 0974-7907 (online) | 0974-7893 (print)

Editor: Krushnamegh Kunte

\section{Manuscript details:}

Ms \# 02417

Received 03 March 2010

Finally accepted 16 March 2010

Citation: Smetacek, P. (2010). Subspecific status of the southern Indian population of Nyctemera coleta (Lepidoptera: Arctiidae). Journal of Threatened Taxa 2(4): 835-836.

Copyright: (c) Peter Smetacek 2010. Creative Commons Attribution 3.0 Unported License. JoTT allows unrestricted use of this article in any medium for non-profit purposes, reproduction and distribution by providing adequate credit to the authors and the source of publication.

Acknowledgements: I am indebted to Prof. K. Gunathilagaraj and the authorities of the Agricultural University, Coimbatore for kindly supplying specimens of this moth, to Dr. I.J. Kitching at the Natural History Museum, London, U.K. for kindly comparing this material with specimens in the collection there, to Julie Valsarajan, Bengaluru, Karnataka and Kousik Nandy, Bengaluru, Karnataka, for photographing this moth in southern India and thereby alerting me to its presence there and especially to Sameera Karunarathna for kindly helping me with photographs of Sri Lankan specimens.

\section{OPEN ACGESS I FREE DOWNLOAD (C) (i) (4)}

specimen on 16 November 2004 near Muthadi Nature Camp, Bhadra Wildlife Sanctuary, about 35km from Chikkamagaluru in Karnataka.

Since $N$. coleta nigrovenosa is found in Sri Lanka, it was thought desirable to establish the sub-specific status of the southern Indian population of this moth, since it could belong either to the nominate subspecies, nigrovenosa or to an intermediate form.

Prof. K. Gunathilagaraj of the Agricultural University, Coimbatore kindly sent six specimens consisting of five males and a female from southern India for critical examination. The data labels on the males are identical as follows: Light/Thadiyankudisai/27.06.08/NPIB-CBE; forewing length $24-28 \mathrm{~mm}$. The data label of the female states: Light trap/Myladumpara/03.06.08/NPIB-CBE; forewing length: $25 \mathrm{~mm}$.

Unfortunately, the species is not illustrated in Holloway (1988) due to an error of omission.

The male genitalia of one specimen examined was identical to those figured in Holloway (1988) and Arora (1983). Hampson (1894) stated that the form nigrovenosa from Ceylon (= Sri Lanka) has veins 3 and 4 (= Cu1 A and M3 respectively) of the hindwing black and the spots of the postmedial band of forewing smaller (than N. C. coleta).

Since some of the material examined in the present study approached this description, a photograph of these specimens was sent to the Natural History Museum, London, for comparison with specimens of nigrovenosa contained therein.

Dr. I.J. Kitching kindly compared this photo with specimens in the collection of the NHM and concluded that although both $N$. c. coleta and $N$. c. nigrovenosa have black lines running basad along the hindwing veins from the marginal black bands, in $N$. c. coleta, these lines stop before the discal cell while in $N$. c. nigrovenosa, the black along $\mathrm{M}$ and Cu1A (and sometimes others in heavily marked specimens) not only reaches the cell but continues along the cubital vein almost to the wing base. This feature is not found in any of the southern Indian material, so they appear to be $N$. coleta coleta.

Therefore, it seems that the mainland Indian population as well as the population on the Andaman Islands (Arora 1983) belongs to $N$. c. coleta and $N$. c. nigrovenosa is restricted to Sri Lanka.

\section{REFERENCES}

Arora, G.S. (1983). On The Lepidopterous Fauna of Andaman and Nicobar Group of Islands (India): Family Arctiidae. Records of the Zoological Survey of India, Occasional Paper No. $60,49 p p+3 p l s$.

Beccaloni, G.W., M.J. Scoble, G.S. Robinson \& B. Pitkin (eds.) (2003). The Global Lepidoptera Names Index (LepIndex). World Wide Web electronic publication. http://www.nhm. ac.uk/entomology/lepindex [accessed 5 January 2009] 


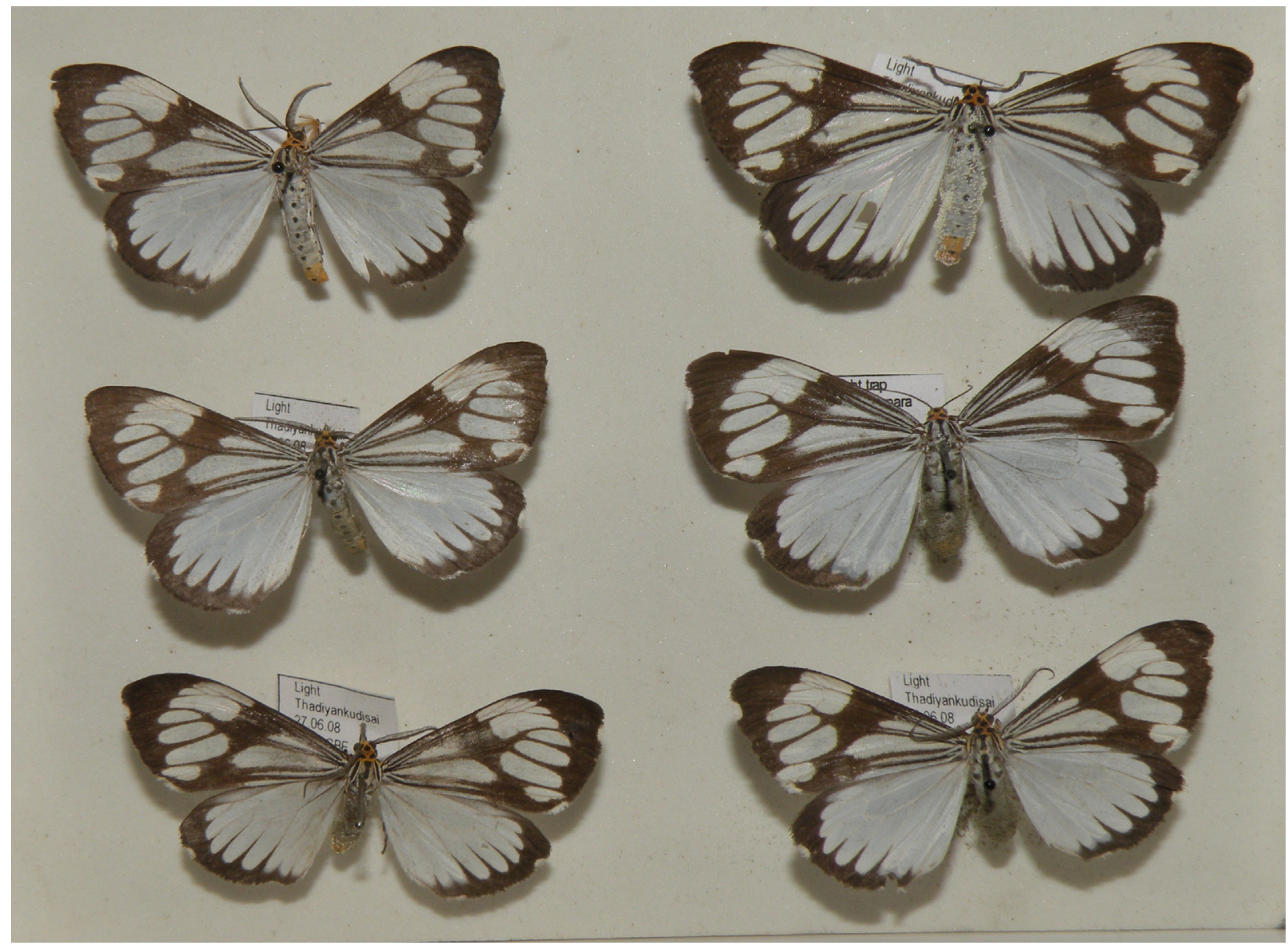

Image 1. Specimens of southern Indian Nyctemera coleta examined in the present study. Female is in centre of right row.

Hampson, G.F. (1894). The Fauna of British India including Ceylon and Burma. Moths Vol. 2. Taylor and Francis, London, $609 p p+22 p l s$.

Holloway, J.D. (1988). The Moths of Borneo. Part 6. Arctiidae, Syntominae, Euchrominiinae, Arctiinae, Aganainae (to Noctuidae). Southdene Sendirian Berhad, Kuala Lumpur, $101 \mathrm{pp} .+17+6 \mathrm{pls}$. 